Primljen / Received: 28.11.2011

Ispravljen / Corrected: 21.7.2012.

Prihvaćen / Accepted: 31.8.2012.

Dostupno online / Available online: 15.9.2012.

\section{Effect of foundation in dynamic analysis of concrete gravity dams}

Autori:

Preliminary note

Zahra Heirany, Mohsen Ghaemian

\section{Effect of foundation in dynamic analysis of concrete gravity dams}

In this paper, nonlinear dynamic analysis of concrete gravity dams was studied. To investigate the effect of dam-reservoir-foundation interaction, a two-dimensional approach was used including the finite element method, and smeared crack approach. The dam-reservoir interaction is solved by staggered solution procedure while the Sharan boundary condition is applied at the reservoir's far-end truncated boundary. The foundation is defined as a part of the structure and some different boundary conditions such as Lysmer, Boulder and damper boundary conditions are applied at its truncated boundaries. Results show that when the nonlinear analysis includes the dam - foundation interaction and the foundation's mass, flexibility and radiation damping, the gravity dam's response will be acceptable.

Key words:

concrete gravity dams, dam-reservoir-foundation interaction, boundary condition

Prethodno priopćenje

\section{Zahra Heirany, Mohsen Ghaemian}

\section{Utjecaj temelja na dinamičku analizu betonskih gravitacijskih brana}

U članku se opisuje nelinearna dinamička analiza betonskih gravitacijskih brana. Zbog analize međudjelovanja akumulacije i temelja upotrebljavaju se dvodimenzionalni pristup i metoda konačnih elemenata uz primjenu modela razmazanih pukotina. Međudjelovanje brane i akumulacije riješeno je prikladnim rastavom sustava jednadžbi, dok je Sharanov rubni uvjet primijenjen na najudaljeniji rub akumulacije. Temelj je definiran kao dio konstrukcije pa se na njegove rubove primjenjuju drugačiji rubni uvjeti poput Lysmarovog i Boulderovog te rubnog uvjeta s prigušivačima. Rezultati pokazuju da je odziv gravitacijske brane zadovoljavajući kada se u nelinearnu analizu uključi međudjelovanje brane i temelja, masa temelja, fleksibilnost i radijacijsko prigušenje.

Ključne riječi:

betonske gravitacijske brane, međudjelovanje brana - akumulacija - temelji, rubni uvjet

Vorherige Mitteilung

\section{Zahra Heirany, Mohsen Ghaemian}

\section{Einfluss des Fundaments auf die dynamische Analyse von Betongewichtsstaumauern}

In dem Artikel wird die nicht-lineare dynamische Analyse von Betongewichtsstaumauern analysiert. Zum Zwecke der Analyse der Wechselwirkung von Talsperre, Speicher und Fundament wurde die zweidimensionale Vorgehensweise und die Finite-Elemente-Methode unter Anwendung des verschmierten Rissmodells angewendet. Die Wechselwirkung der Talsperre und des Speichers wurde durch die entsprechende Zerlegung des Gleichungssystems gelöst, während die Sharan - Randbedingung an dem am weitesten gelegenen Speicherrand angewendet wurde. Das Fundament ist als Teil der Konstruktion definiert, so dass auf seine Ränder andere Randbedingungen, wie z.B. Lysmer- und Boulder sowie jene von Tilgern angewendet werden. Die Resultate zeigen, dass die Einflussreaktion der Gewichtsstaumauern befriedigend ist, wenn in der nicht-linearen Analyse die Wechselwirkung von Talsperre und Fundament, Fundamentmasse, Elastizität und Strahlungsdämpfung mit eingerechnet werden.

Schlüsselwörter:

Betongewichtsstaumauern, Zwischenwirkung der Talsperren - Speicher - Fundamente, Randbedingung, 


\section{Introduction}

Safety evaluation of dynamic response of dams is important for most of researchers. When such system is subjected to an earthquake, hydrodynamic pressures that are in excess of the hydrostatic pressures occur on the upstream face of the dam due to the vibration of the dam and impounded water. Consequently, the prediction of the dynamic response of dam to earthquake loadings is a complicated problem and depends on several factors, such as interaction of the dam with rock foundation and reservoir, and the computer modeling and material properties used in the analysis. Therefore, an efficient method is required to properly assess the safety of a concrete gravity dam located in regions with significant seismicity.

Some methods have been introduced for the dam-reservoirfoundation interaction. Fenves and Chopra [1] studied the dam-water-foundation rock interaction in a frequency domain linear analysis and developed a computer finite element program called EAGD-84 [2]. Then, Leger and Bhattacharjee [3] presented a method which is based on frequency-independent models to approximate the representation of dam-reservoir-foundation interaction. In the work presented by Gaun et al. [4], an efficient numerical procedure has been described to study the dynamic response of a reservoir-dam-foundation system directly in the time domain. Later, Ghaemian, Noorzad and Moradi Moghaddam [5] showed that the effects of foundation's shape and mass on the linear response of arch dams are considerable. It is wise and economical to truncate the far-end boundaries of the foundation. Probably the most widely used model for soil radiation damping is the one of Lysmer and Kuhlemeyer [6]. In this model the foundation is wrapped by dashpots tuned to absorb the $\mathrm{S}$ and $\mathrm{P}$ waves; however this model ignores the interaction of the foundation and free field. This interaction is accounted for by the more refined model of Miura and Okinaka [7], however this model requires four separate analyses of free field in 2D. Saouma [8] proposed another boundary condition called Boulder Recommendation using some springs and dampers at the vertical truncated boundaries. Although Boulder Recommendation benefits the same Lysmer formulation for dampers, it introduces an efficient formulation for utilizing springs. Finally, it is necessary to mention the work done by Wilson [9] that presents a method called Soil Structure Interaction Method (SSI) for estimation of free field earthquake motions at the site of dams. This method neglects the presence of structure (dam) during the earthquake and assumes that the relative displacement at the truncated boundary is zero, and shows that under these circumstances, the foundation just bears the inertia force and does not bear the earthquake force. In the present article, a two dimensional dam-reservoir-foundation system is analyzed nonlinearly using finite element method and smeared crack approach.
The dam-reservoir interaction is solved by staggered solution procedure while the Sharan Boundary condition is applied at the reservoir's far-end truncated boundary. The foundation is defined as a part of the structure and some different boundary conditions are applied at its truncated boundaries.

\section{Dam-reservoir interaction}

The equation of motion of reservoir can be represented by Helmholtz's equation in the following form:

$\frac{1}{C^{2}} \ddot{p}=\nabla^{2} p$

where $\mathrm{P}$ and $\mathrm{C}$ are hydrodynamic pressure and speed of pressure wave in water, respectively.

Boundary condition at the free surface in the reservoir is written as:

$p=0$

The included boundary condition that could model complete absorption of propagating waves at the far-end boundary of reservoir is called Sharan [10] boundary condition and represented as follow:

$\frac{\partial p}{\partial n}=-\frac{\pi}{2 h} p-\frac{1}{C} \dot{p}$

where $\mathrm{h}$ is the height of reservoir and $\mathrm{n}$ is the vector normal to the surface.

At bottom and sides of reservoir, Helmholtz's equation is used in sediment field, assuming only vertical excitation of hydrodynamic pressure waves and the following equation is achieved:

$\frac{\partial p}{\partial n}-q \frac{\partial p}{\partial t}=-\rho a_{n}^{s}$

where $a_{n}^{s}$ is normal acceleration of the dam at the interface.

$q=\frac{1-k}{(1+k) C}$

Where $\mathrm{C}$ and $\mathrm{k}$ are velocity of pressure wave at bottom and sides of reservoir and wave reflection coefficient, respectively.

\section{The dam-reservoir-foundation-interaction}

The effect of dam-reservoir-foundation interaction is considered with two differential equations of the second order that can be written as follows:

$$
\begin{aligned}
& {[M]\{\ddot{u}\}+[C]\{\dot{u}\}+[K]\{u\}=\left\{f_{1}\right\}-[M]\left\{\ddot{u}_{g}\right\}+[Q]\{p\}} \\
& {[G]\{\ddot{p}\}+\left[C^{\prime}\right]\{\dot{p}\}+\left[K^{\prime}\right]\{p\}=\left\{F_{2}\right\}-\rho[Q]^{T}\{\ddot{u}\}}
\end{aligned}
$$

Where $[\mathrm{M}],[\mathrm{C}]$ and $[\mathrm{K}]$ are mass, damping and stiffness matrices of structure including dam and foundation and [G], [C'] and [K'] 
are the corresponding mass, damping and stiffness matrices of the reservoir, respectively. [Q] is the coupling matrix and $\left\{\mathrm{f}_{1}\right\}$ is the vector of body force and hydrostatic force. $\left\{\mathrm{F}_{2}\right\}$ is the component of the force due to acceleration at the boundaries of the dam-reservoir and reservoir-foundation. $\{p\}$ and $\{u\}$ are the vectors of pressures and displacements. $\left\{\ddot{u}_{\mathrm{g}}\right\}$ is the ground acceleration and $\rho$ is the density of the fluid. The dot represents the time derivative.

\subsection{Boundary conditions}

\subsubsection{Lysmer boundary condition}

Three boundary conditions are used for this research for both of mass-less and massed foundation. The first of which is the Lysmer boundary condition that was represented by Lysmer and Kuhlemeyer [6] and is shown in Figure 1. There are horizontal and vertical dampers on both sides of foundation but at the base only there are rollers. This boundary condition is defined using Lysmer's theory about radiation damping. According to this theory, the surrounding boundaries could be modeled using normal and tangential dampers. In a finite element model, the damping factor of these dampers can be calculated as follows [6]:

$$
\begin{aligned}
& C_{11}^{i}=V_{P} \rho \int_{l_{\mathrm{e}}} N_{i} d l \\
& C_{22}^{i}=V_{S} \rho \int_{l_{e}} N_{i} d l
\end{aligned}
$$

$\mathrm{C}_{11}$ and $\mathrm{C}_{22}$ are the damping factors in the normal and tangential directions respectively and $\mathrm{N}_{\mathrm{i}}$ is the element shape function. Where the velocity of pressure and shear waves $\left(V_{p}\right.$ and $\mathrm{V}_{\mathrm{s}}$ ) are calculated as follows [6]:

$G=\frac{E}{2(1+v)}$

$V_{s}=\sqrt{\frac{G}{\rho}}$

$S^{2}=\frac{1-2 v}{2(1-v)}$

$V_{P}=\frac{1}{S} V_{S}$

Where $G, E, \rho$ and $v$ are shear modulus, modulus of elasticity, mass density and Poisson's ratio of foundation respectively.

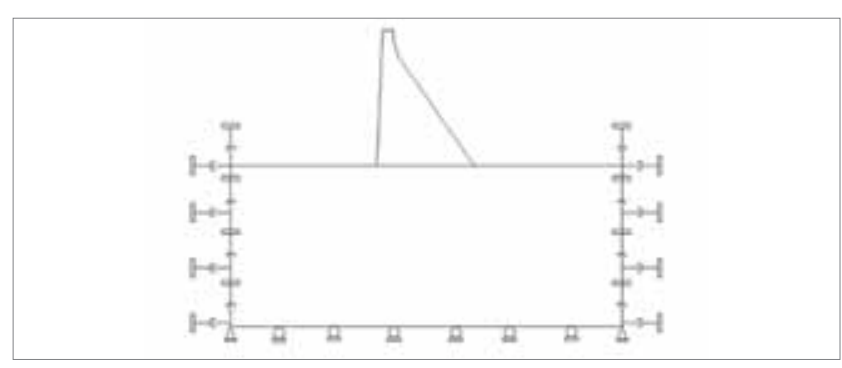

Figure1. Lysmer Boundary condition

\subsubsection{Boulder boundary condition}

Boundary condition that is shown in Figure 2 and called Boulder boundary condition is like Lysmer boundary condition but includes horizontal springs at one side of foundation. The dampers' damping factor can be calculated from equation 8 and 9. The springs' stiffness is computed by equation 14 :

$K_{m}=\frac{E A}{h}$

where $E$ is the foundation's modulus of elasticity, $A$ the tributary area of the node connected to the spring, and $\mathrm{h}$ is a representative equivalent depth of the foundation [8].

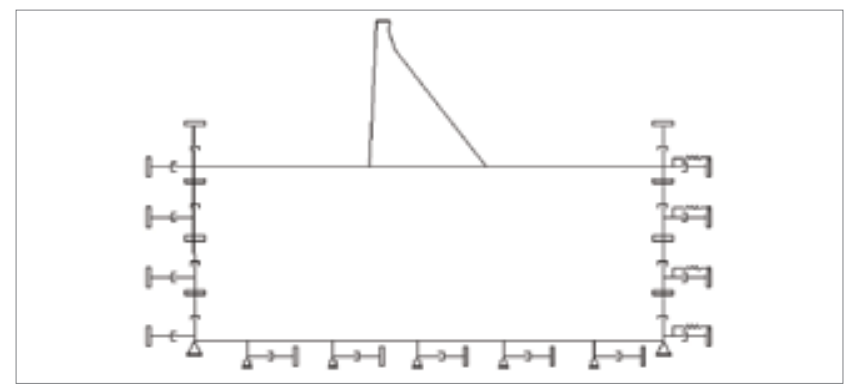

Figure 2. Boulder Boundary condition

\subsubsection{Damper boundary condition}

Figure 3 shows a boundary condition that includes horizontal and vertical dampers at both sides and at the base of foundation with rollers. The point in combining rollers and vertical dampers at the bottom boundary is that vertical damper has very negligible effect in absorption of the outgoing waves.

The dampers' damping factor can be calculated from equation (8) and (9).

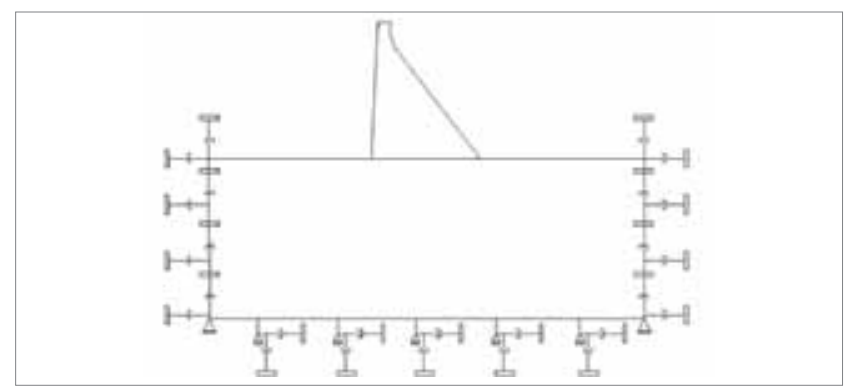

Figure3. Damper Boundary condition

\section{Nonlinear analysis}

The smeared crack model introduced by Bhattacharjee and Leger [11] is used to evaluate the nonlinear behavior of concrete gravity dams with dam-reservoir-foundation interaction using the staggered method of solution that was proposed by Ghaemian and Ghobarah [12]. 


\subsection{Numerical results}

\section{Case study: Pine Flat Dam}

The tallest monolith of the Pine Flat Dam, located in California (Figure 4), is selected for evaluating the results obtained by computer code, NSAG-DRI [13] that was used to carry out the nonlinear analysis. The reason of this selection is that this dam was the subject of many experimental and theoretical studies. It's structure has crest length of $560 \mathrm{~m}$ and consists of 37 monoliths 15.2 wide that the tallest of which is $122 \mathrm{~m}$.

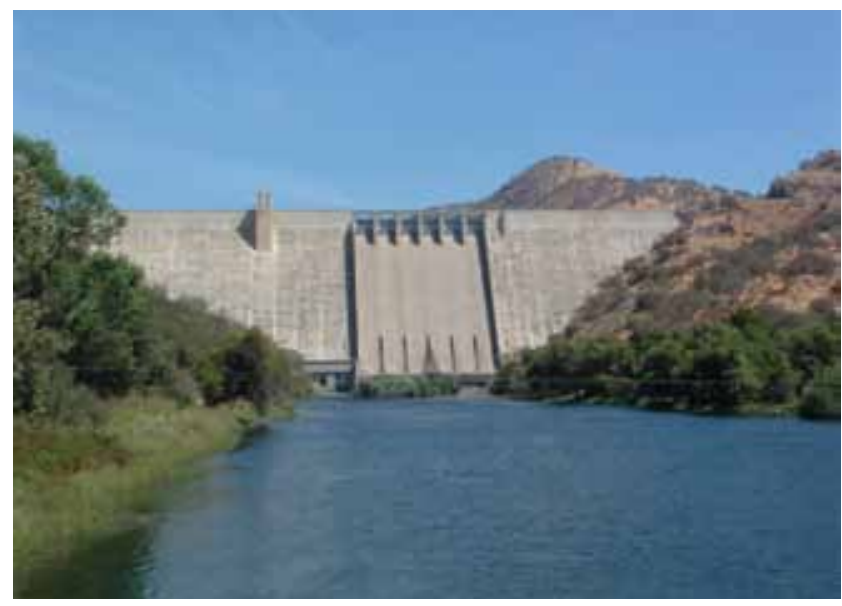

Figure4. Pine Flat Dam

The 4-node, quadrilateral, isoparametric finite element model of this monolith in plane stress has been illustrated in Figure 5. The model had 5664 nodes ( 3768 nodes at foundation) and 5512 elements.

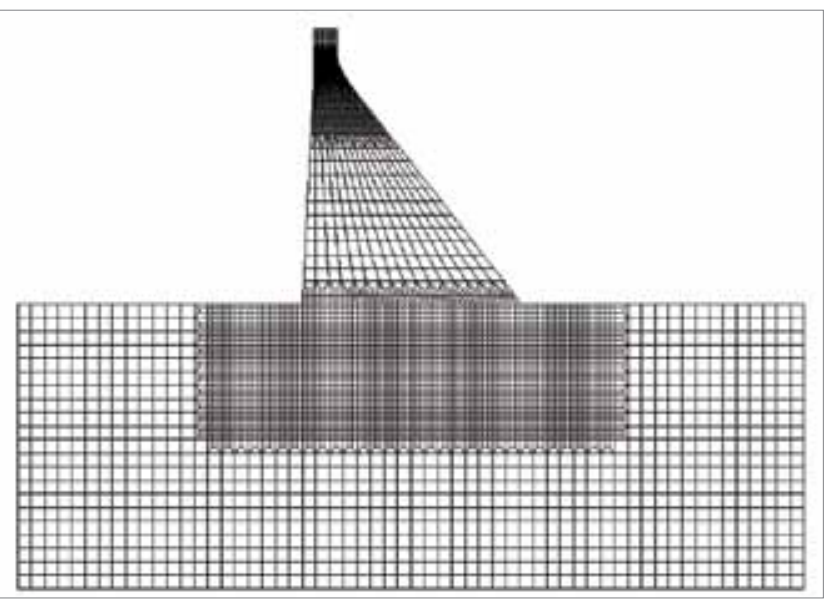

Figure5. Finite element model of the tallest monolith of Pine Flat Dam

The parameters that used in this research are those which Ghaemian and Ghobarah included at their models [14]. Basic parameters such as modulus of elasticity, unit weight and Poisson's ratio of concrete dam are chosen as $27.58 \mathrm{GPa}, 2400$ $\mathrm{kg} / \mathrm{m}^{3}$ and 0.20 , respectively. The modulus of elasticity, unit weight and Poisson's ratio of rock foundation are selected as $22.4 \mathrm{GPa}, 2643 \mathrm{~kg} / \mathrm{m}^{3}$ and 0.33 , respectively. The tensile strength and fracture energy of concrete dam are taken to be $3.05 \mathrm{Mpa}$ and $300 \mathrm{~N} / \mathrm{m}$. A dynamic magnification factor of 1.2 is considered for the tensile strength and fracture energy [14]. It is assumed that foundation has linear behavior in all of the models. The length and depth of the foundation are $348 \mathrm{~m}$ and $126 \mathrm{~m}$, respectively.

The reservoir's length is ten times as long as the water level in reservoir and the Figure 6 shows the finite element model of reservoir. Sharan boundary condition is used for truncated far end of reservoir [10]. The velocity of pressure wave in water and wave reflection coefficient is taken $1438.66 \mathrm{~m} / \mathrm{sec}$ and 0.82 respectively.

For the purpose of the seismic analysis of dam, Manjil earthquake record is used (Figure 7.).

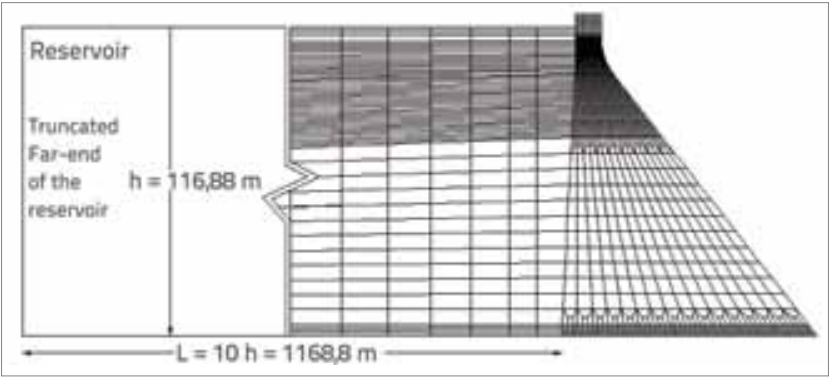

Figure 6. Finite element model of reservoir

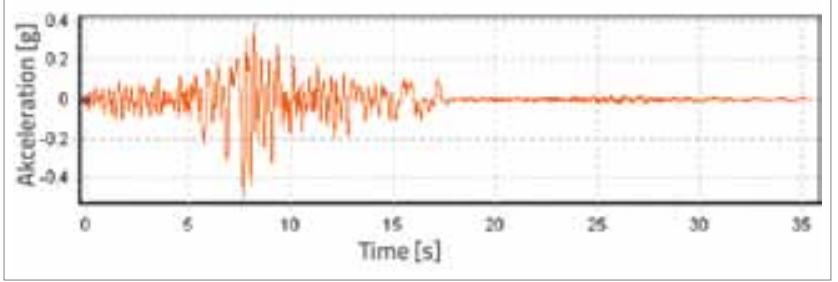

Figure 7. Manjil earthquake 1990, Station:Tonekabun

\subsection{The effect of foundation mass}

In order to consider the effect of foundation's mass, nonlinear dynamic analyses were carried on mass-less and massed foundations with Lysmer, Boulder and Damper boundary conditions. The results of the crack profiles are represented for both foundations, mass-less and massed with three boundary conditions at the following figures.

The results of mass-less foundation show that in Lysmer boundary condition, there is decreasing of crack profiles and displacement of dam crest. After Lysmer, Boulder and then Damper boundary condition lead to less crack profiles due to high absorption of energy.

In Boulder boundary condition time history ending is at $4 \mathrm{sec}$ that this is due to excessive damage of the structure. Lysmer and Damper boundary conditions have similar flexibility due to use dampers in both sides but Boulder boundary condition 
is more rigid because of horizontal springs that cause more displacement of dam crest (Figures 8. and 9.).

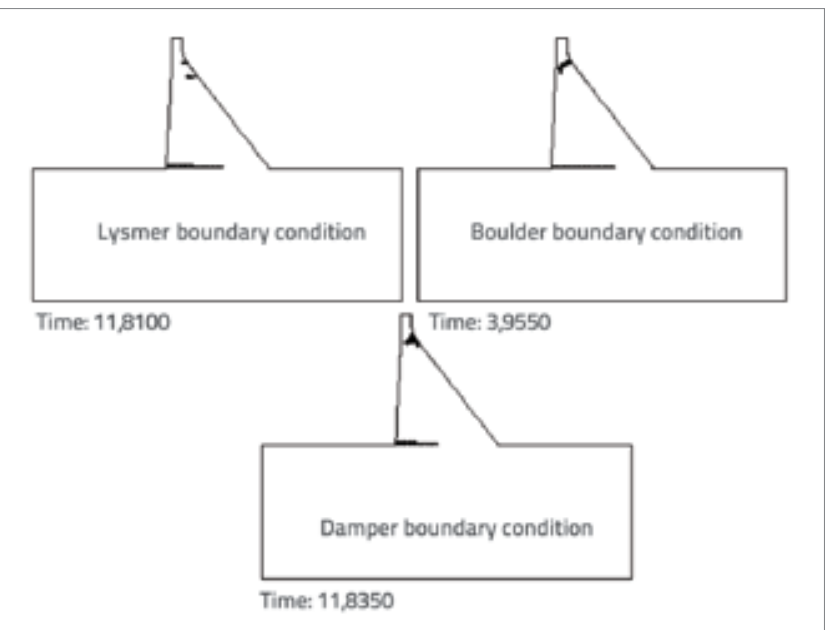

Figure 8. Crack profiles of system for mass-less foundation by varying boundary conditions

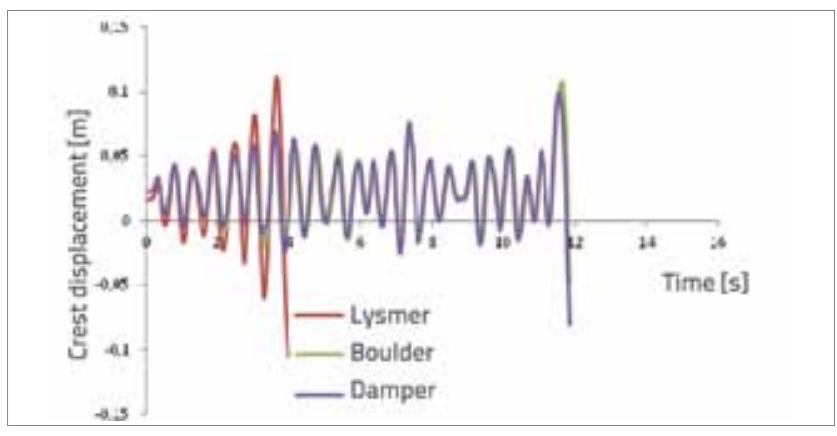

Figure 9. Maximum displacement of dam crest in mass-less foundation by varying boundary conditions

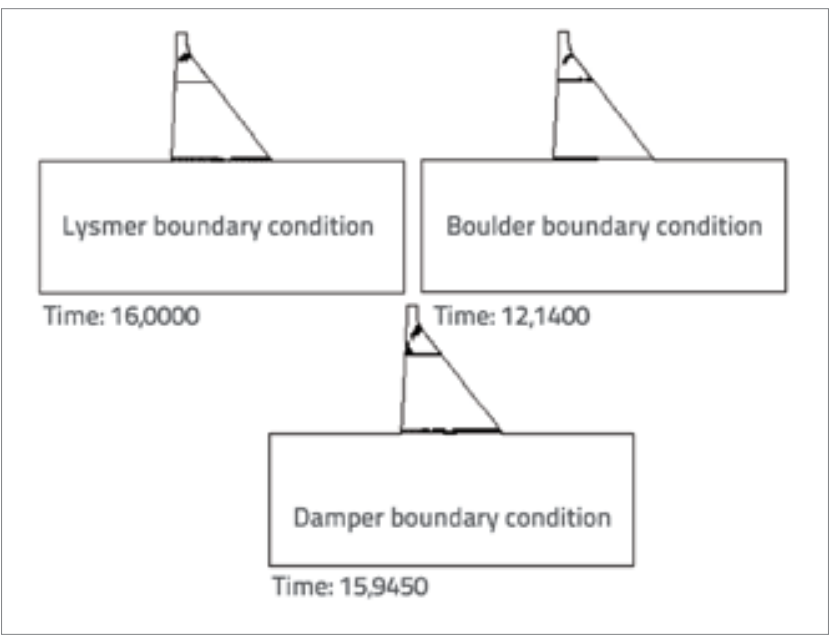

Figure 10. Crack profiles of system for massed foundation by varying boundary conditions
Figures 10 and 11 show the results of massed foundation with three boundary conditions. Lysmer and Damper boundary conditions show a very negligible effect on the crack profiles because of using dampers that causes these boundary conditions more flexible. But in Boulder boundary condition the crack profiles has been decrease substantially due to include horizontal springs. Decreasing of maximum displacement of dam crest in Lysmer and Damper boundary conditions comparing Boulder boundary condition is because of more flexibility too.

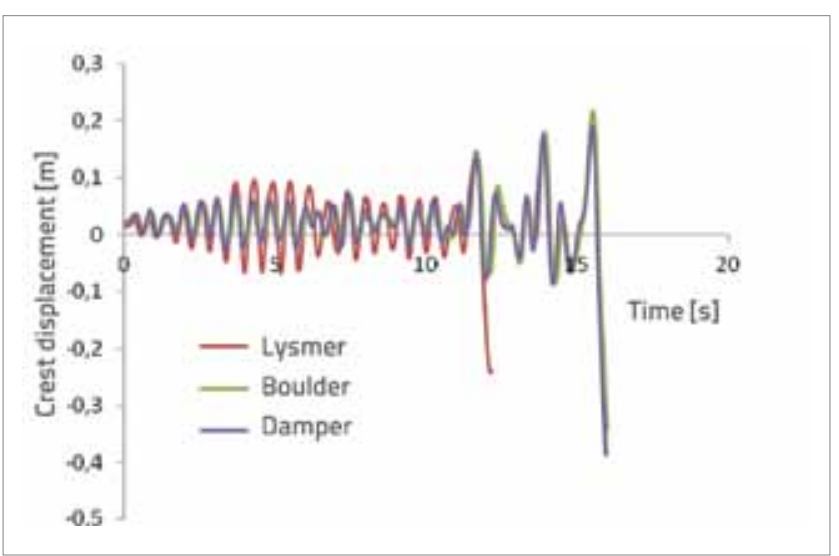

Figure 11. Maximum displacement of dam crest in massed foundation by varying boundary conditions

\section{Conclusion}

When the nonlinear analysis includes the dam-foundation interaction, the gravity dam's response will be more realistic. In mass-less foundation, it's considered only flexibility and structural damping, neglecting inertia and geometric damping. Then time history of displacement of dam crest increases and it's concluded that nonlinear dynamic analysis of mass-less foundation is overestimated.

Considering the geometric damping in nonlinear dynamic analysis of massed foundation decreases time history of displacement of dam crest then damage in system is decreased.

In mass-less foundation Lysmer boundary condition can decrease crack profiles and maximum displacement of dam crest. But in massed foundation, the time required for Boulder boundary condition to reach the excessive damage is higher than two others while the crack profiles show less damage for Boulder boundary condition than the other two and this is due to use horizontal springs in Boulder boundary condition. Horizontal springs decrease flexibility and the system will be more rigid then cause the less damage in crack profiles and more displacement of dam crest. 


\section{REFERENCES}

[1] Fenves, G., Chopra, A.K.: Earthquake Analysis of Concrete Gravity Dams Including Reservoir Bottom Absorption and Dam-WaterFoundation Rock Interaction, Earthquake Engineering and Structural Dynamics, 12 (1984) 5, 663-680.

[2] Fenves, G., Chopra, A.K.: EAGD84: A Computer Program for Earthquake Analysis of Concrete Gravity Dams, Report No. UCB/ EERC 86/09, University of California, Berkeley, (1984).

[3] Leger, P. \& Bhattacharjee, S.S.: Reduced Frequency-Independent Models for Seismic Analysis of Concrete Gravity Dam, Computer and Structures, 44 (1992) 6, 1381-1387.

[4] Gaun, F., Moore, I.D., Lin, G.: Seismic Analysis of ReservoirDam-Soil Systems in the Time Domain, Computer Methods and Advances in Geomechanics, (1994), 917-922.

[5] Ghaemian, M., Noorzad, A., Moradi Moghaddam, R.: Foundation Effect on Seismic Response of Arch Dams Including DamReservoir Interaction, Europe Earthquake Engineering, (2005), 49- 57.

[6] Lysmer, J., Kuhlemeyer, R.L.: Finite Dynamic Model for Infinite Media, Journal of Engineering Mechanics Division, ASCE, 95(1969), 859-877.

[7] Miura, F., Okinaka, H.: Dynamic Analysis Method for 3D SoilStructure Interaction Systems with the Viscous Boundary Based on the Principle of Virtual Work, Japanese Journal of Civil Engineering, (1989), 395-404.
[8] Saouma V.: Course Note, Chapter 8: Nonlinear Dynamic Analysis of Dams.

[9] Wilson, E.L.: Three Dimensional Static and Dynamic Analysis of Structures, A Physical Approach with Emphasis on Earthquake Engineering, $4^{\text {th }}$ Ed., Computers and Structures Inc,(2000).

[10] Sharan, S.: Modeling of radiation damping in fluids by finite elements, International Journal for Numerical Methods in Engineering, 23 (1986), 945-957.

[11] Bhattacharjee, S.S., Leger, P.: Seismic cracking and energy dissipation in concrete gravity dams, Earthquake Engineering \& Structural Dynamics, 22 (1993), 991-1007.

[12] Ghaemian, M., Ghobarah, A.: Staggered Solution Schemes for Dam-Reservoir Interaction, Journal of Fluid and Structures, 12 (1998), 933-948.

[13] Ghaemian, M.: Manual of NSAG-DRI, a computer program for nonlinear seismic analysis of gravity dams including damreservoir-foundationinteraction, (2008).

[14] Ghaemian, M., Ghobarah, A.: "Nonlinear seismic response of concrete gravity dams with dam-reservoir interaction", Engineering Structures, Vol.21, pp. 306-315 /1999. 